\title{
A Comparison of Mathematics Teachers' Attitudes Towards Coeducational Secondary Schools' Mixed and Gender Streamed Classes in Nakuru, Uasin Gishu, Kericho and Baringo Counties of Kenya
}

\author{
A. C. Barmao*, B. N. Githua, J. M. Changeiywo \\ Department of Curriculum, Instruction and Education Management, Egerton University, Nakuru, Kenya
}

Email address:

barmaoanne@yahoo.com (A. C. Barmao),bgithua2002@yahoo.com (B. N. Githua), jchangeiywo@yahoo.com (J. M. Changeiywo)

To cite this article:

A. C. Barmao, B. N. Githua, J. M. Changeiywo. A Comparison of Mathematics Teachers' Attitudes Towards Coeducational Secondary Schools' Mixed and Gender Streamed Classes in Nakuru, Uasin Gishu, Kericho and Baringo Counties of Kenya. Education Journal.

Vol. 4, No. 5, 2015, pp. 238-244. doi: 10.11648/j.edu.20150405.18

\begin{abstract}
The study compared mathematics teachers' attitudes towards mixed sex and gender streamed (boys' and girls' only) classes all organized in public coeducational secondary schools of Nakuru, Uasingishu, Kericho and Baringo Counties of Kenya. An ex post facto causal comparative research design was used. Purposive and stratified random sampling techniques were used to select 20 co-educational secondary schools each from two school categories (county and sub-county) and types (those with mixed sex and gender streamed classes). Two mathematics teachers from each class type were selected from each school based on gender stratification where possible giving a total of 203 teachers. A mathematics teachers' attitude questionnaire named (MTAQ) was used to collect data. This instrument was piloted and validated to improve it before use and a reliability coefficient of 0.87 using Chronbach alpha obtained. This was considered appropriate as it was within the accepted threshold of 0.70 and above in social science research. The collected data was then analyzed using both descriptive statistics (means, standard deviation and percentages) and inferential statistics (ANOVA) at a confidence level of 0.05 . The results of the study revealed that mathematics teachers' attitudes were lower towards girls' only classes as compared to boys' only and mixed sex classes in both county and sub-county co-educational schools. The statistical tests of significance show that there were statistically significant differences in county schools' mathematics teachers' attitudes while there were no significant differences in sub-county schools. The results from the study have yielded valuable information that may be used to inform the intervention in Kenya's coeducational secondary schools and advice policy makers, teachers and administrators of the schools on appropriate measures to undertake to enhance its effectiveness in the teaching and learning of mathematics.
\end{abstract}

Keywords: Coeducational Secondary School Mathematics Teachers' Attitudes, Gender Streamed (Boys' and Girls' Only) Classes, Mixed Sex Classes, Mathematics, Kenya

\section{Introduction}

The major goal of most developing countries including Kenya is to achieve high levels of technological advancement. In order to achieve this goal, the citizens of the countries should among other skills be competent in mathematics (Hodgen \& Marks, 2013). This is because the skills acquired in the subject provide the country with a human resource that is highly educated and able to tackle most of the country's problems (Ahuja, 2006; Norris, 2012). Hence, it is imperative that students excel in the subject especially in secondary school, since a good grade in the subject at this level is a criterion for enrollments in advanced science, mathematics and technology courses in colleges and universities (Ofsted, 2011). However, the performance of students at the KCSE mathematics examinations in Kenya has been dismal for many years (Kenya National Examination Council reports 2003-2013). According to the Kenya National Examination Council (KNEC) reports of 2003 to 2013, in addition to the poor general performance, majority of the girls in particular have been performing poorly in the subject compared to the boys. Studies conducted to establish the cause of this scenario have accused teachers in mixed sex classroom learning environments of fostering unequal treatment of males and 
females (Mukwaa \& Too, 2005). As a possible remedy to this, single sex classes within coeducational secondary schools were created. There is however limited research, which has been carried out to establish the impact of this intervention on mathematics teachers' attitude. Therefore, the researchers in this study address themselves to comparing the attitudes of teachers teaching gender streamed and mixed sex classes all organized in coeducational secondary schools in order to ascertain the influences of the intervention on mathematics teachers' attitudes.

Attitudes refer to feelings directed towards or away from some target (Husen \& Postlethwaite, 1991). It involves emotion, target, direction, intensity and consistency. Ahmad and Sahak (2009) contend that attitude influences peoples' views, actions, thinking and what they are likely to hear. These attitudes are as a result of experiences and determine how individuals tend to respond favorably or unfavorably to an object or situation. In this study, attitudes referred to the intensity and strength of the teachers' feelings directed towards or away from their mathematics classes.

Kreiter and Kinicki (2007) have argued that attitudes are in three categories; affective, cognitive and behavioral. Attitude is affective when it touches on individuals' feelings or emotions towards an object or situation. It is cognitive, when it influences peoples' beliefs or ideas and lastly it is behavioral if it influences individual's behavior towards an object or situation. Therefore, the attitudes of an individual towards an object or situation will influence how they feel, think and behave towards the same. Hence in this study, the teachers' attitudes towards their mathematics classes referred to their feelings when teaching mathematics in mixed and gender streamed (boys' and girls' only) classes within coeducational secondary schools.

Teachers are very important persons to the learners. Learners perceive them as always true and right. Ahmad and Sahak (2009) have argued that learners perceive their teachers as role models both inside and outside the classroom. Rose (2005) agrees with the above assertion by further adding that as role models teachers can expose their learners to certain attitudes, lifestyles and outlooks. Carr (2000) supports Rose and Ahmad and Sahak (2009) by arguing that learners rate the teachers and parents to be at par in role modeling. Chouinard (2008) further adds that parents and teachers play an important role in shaping a student's attitude towards mathematics. Chouinard contends that, parents' attitudes towards mathematics and towards their children as learners of the subject affects the children perceptions of their competence and values attached to mathematics. Teachers have also been found to affect students' feelings about certain subjects. This can be achieved through making their subjects enjoyable thereby making learners to feel successful in class. As a result, students are more likely to have a better attitude towards the class and may want to come to it (Chouinard, 2008).

Apart from being role models, Teo (2008) asserts that teachers are key change agents in any school. They play crucial roles in the success of initiatives or policies initiated in schools. The success of school policies and initiatives is a function of the teachers' support and attitudes. It is important therefore for these teachers to possess positive attitudes towards streaming in mathematics classes since this attitudes are linked to their commitment to the policy. According to Kreiter \& Kinicki (2007) job satisfaction is likely to affect teacher-student interaction. They continue to assert that effective communication is vital in creating and maintaining an effective school policy. The success of policies in school is directly linked to what teachers feel about it.

The teachers' attitudes towards boys and girls as learners of mathematics may influence their behavior towards them in mathematics classes. These teachers' attitudes will determine learners' perceptions and expectations of their performance (Gina \& Moshe, 2001; Pahle, Hyde \& Allison, 2014). It will also influence their relationship and interaction with learners in mathematics classes (Gina \& Moshe, 2001; Ahmad \& Sahak, 2009). These teacher attitudes are largely influenced by the general societal stereotypes. Fryer and Levitt (2010) and Mukwa and Too (2005) add that teachers treat boys and girls differently and use teaching methods that depict the societal norms and beliefs about gender differences. These teacher actions will in turn affect the learners' thinking, questioning, problem solving and classroom discussions.

Mc Coy, Smyth and Burke (2012) and Changeiywo (2000) observed that there are differences in the way teachers interact with boys and girls in coeducational mathematics and science classes. They observed that boys seek out and receive a lot of teacher attention. Teachers call upon more on male students than females' students to answer questions and participate in class demonstrations. These teacher actions make the female students to be passive, develop low self esteem, loose interest and perform poorly. This finding is supported by Gina and Moshe (2001) who found that teachers perceive boys as their best mathematics students and hence concentrate more on them than the girls. Mc Coy et al also reported that apart from the differential treatment of males and females in a coeducational classes by teachers, girls' in single sex primary schools in Ireland are more likely to have positive attitudes towards mathematics than their counterparts in a coeducational setting. For boys, the same study observed that, they were more positively disposed towards mathematics than girls. However the study found little differences in attitudes towards mathematics between boys and girls educated in single-sex schools. This could suggest that single sex settings promote positive attitudes towards mathematics of both boys and girls. This study sought to establish the teachers' attitudes towards gender streamed (boys 'and girls 'only) and mixed sex mathematics classes within coeducational secondary schools.

\subsection{Statement of the Problem}

Mathematics is a key subject in the secondary school curriculum in Kenya. Good grades obtained by students in the subject are critical in their enrollment in advanced mathematics, science and technology courses in colleges and universities. Such courses attract high salaries and status and are critical in the country's quest for industrialization and 
technological advancement by the year 2030. However, students' performance in mathematics examinations in Kenya continues to remain very poor in addition to gender disparities in performance in the subject. Boys continue to perform better than the girls. Researchers have pointed out that the mixed sex classroom learning environment could be aggravating this problem. Therefore, in recent years attention has been drawn to addressing this difference in mathematics performance of adolescent boys and girls. This has led to the provision of single sex mathematics classes within co-educational secondary schools. However, there is limited research pertaining to this relatively new phenomenon of gender streamed classes with regard to mathematics teachers' attitudes within co-educational secondary schools. Therefore, this study was designed to establish whether there were significant differences in this teacher attitudes between mixed sex and gender streamed (boys' and girls'; only) mathematics classes by school category.

\subsection{Objective of the Study}

To compare mathematics teachers' attitudes between mixed and gender streamed (boys' and girls' only) classes within co-educational secondary schools by school category (county and sub-county).

\subsection{Hypothesis of the Study}

The null hypothesis was tested at significance level of alpha $(\alpha)$ equal to 0.05 .

Ho1: There is no statistically significant difference in mathematics teachers' attitudes, between mixed and gender streamed classes within co-educational secondary schools by school category.

\section{Methodology}

\subsection{Research Design}

The study adopted an ex post facto causal comparative research design since it was not possible to manipulate the independent variable (Cohen, Manion and Morrison, 2011). Cohen et al (2011) contend that since the independent variable already exists, the investigator sets out to discover possible effects of a phenomenon by comparing the subjects in which the variable is present with similar subjects who do not possess the variable. The design was appropriate for the current study since the independent variable (gender streamed mathematics classes) is a phenomenon that was already in existence in some co-educational secondary schools in Nakuru, Uasingishu, Kericho and Baringo Counties of Kenya. The researchers compared gender streamed classes (boys' and girls' only) with mixed sex classes in these schools on the dependent variable which was mathematics teachers' attitudes.

\subsection{Sampling Procedure and Sample Size}

The sample was selected using purposive, stratified and simple random sampling techniques. Purposive sampling technique was used to select the participating counties. This involved picking counties which had the two types and categories of co-educational secondary schools that were studied. The two types were those with mixed sex and those with gender streamed (boys' and girls' only) classes, while the two categories were the county and sub-county public coeducational secondary schools. Gall, Gall and Borg (2007) recommend that for a causal comparative study, there should be at least 15 participants in each subgroup to be compared. However to take care of situations where some data may be lost or insufficient, the current study selected 20 schools in each school type and category. This gave a total of 80 schools. From each type of mathematics class namely mixed and gender streamed (boys' and girls' only) in each school the researcher randomly selected two mathematics teachers based on gender stratification where possible. This provided a total of 240 mathematics teachers. Table 2 shows how the schools' and mathematics teachers' sample size was arrived at.

Table 1. Schools' and Mathematics Teachers 'Sample Size.

\begin{tabular}{lllll}
\hline & School Type & & \\
\cline { 2 - 5 } & Mixed sex classes & Gender streamed (boys' and girls' only) classes \\
\hline School Category & No of schools & No of teachers & No of Schools & No of teachers i.e 2 from each class type (boys and girl'only classes) \\
Sub-county & 20 & $2 \times 20=40$ & 20 & $4 \times 20=80$ \\
County & 20 & $2 \times 20=40$ & 20 & $4 \times 20=80$ \\
Total & 40 & 80 & 40 & 160 \\
\hline
\end{tabular}

Stratified sampling technique was employed to select the coeducational secondary schools. Schools were stratified based on school category (either county or sub-county) and school type (those with gender streamed classes or those with mixed sex classes). To select the schools, the researcher obtained a list of sub-county and county public secondary schools together with the mobile telephone numbers of the schools' principals from the County Directors of Education of the selected counties. The researcher then contacted each of the principals to obtain information on the type of streaming in their schools. A list of all the schools based on the streaming (those with gender streamed or mixed sex classes) and school category (county or district) was then generated from each county. Proportionate sampling technique was then used to select 20 schools from each school category and type in each of the counties. Once the required number of schools from each county had been determined, simple random sampling was used to select the participating schools. Stratified random sampling based on gender where possible was also used to select the mathematics teachers from each school that participated in the study. However, some questionnaires were found to be incomplete while some teachers did not submit 
some. Therefore' the actual number of valid questionnaires from the teachers was 203.

\subsection{Instrumentation}

In this study, data was collected using a Mathematics Teachers Attitude Questionnaire (MTAQ).MTAQ was developed guided by the one developed by Hiken (1982). The questionnaire had two parts; part A which solicited information on teachers background information in terms of age, sex, teaching load, qualifications, teaching experience and type of mathematics class taught by the teacher. Part B had five point likert-scale items and solicited information on teachers' attitudes towards gender streamed and mixed sex mathematics classes. The instrument was validated and pre tested before actual data collection with a view to improve it. MTAQ was pilot tested in coeducational schools where the respondents' had similar characteristics with the ones in actual sample but did not take part in the study. A reliability coefficient of 0.87 using Cronbach's coefficient formula was obtained.

\subsection{Data Analysis}

Data was analyzed using descriptive statistics (means, standard deviation and percentages) and inferential statistics (one-way ANOVA). To establish where differences in mean scores existed, a post hoc multiple comparison test using scheffe was used. Statistical tests of significance were performed at a significant level of alpha equal to 0.05 .

\section{Results}

\subsection{A Comparison of Mathematics Teachers Attitudes Towards Mixed and Gender Streamed (Boys' and Girls' only) Classes Within Co-educational Secondary Schools by School Category}

Mathematics teachers' attitudes towards gender streamed (girls' and boys' only) and mixed sex classes were determined by school category. These were the sub-county and county categories of coeducational secondary schools. Table 1 gives a descriptive report of sub-county schools' mathematics teachers' attitudes towards mixed and gender-streamed (girls' and boys' only) classes.

Table 2. Mean Scores and SD of Sub-county Schools' Mathematics Teachers' Attitudes towards Gender Streamed (Girls' and Boys' only) and Mixed Sex Classes.

\begin{tabular}{llll}
\hline Class Type & N & Mean Score & SD \\
\hline Boys' Only & 30 & 4.23 & 0.41 \\
Girls' Only & 28 & 3.95 & 0.68 \\
Mixed Sex & 40 & 4.13 & 0.40 \\
\hline
\end{tabular}

The results in Table 1 indicate that the mean scores of teachers' attitude were higher in boys' only classes(4.23) followed by mixed sex classes (4.13) and lastly girls' only classes (3.95) out of the highest possible score of 5. In order to determine whether there were statistically significant differences in the sub-county schools' mathematics teachers' attitude mean scores, an Analysis of variance (ANOVA) was computed and the results summarized in Table 2.

Table 3. ANOVA Results showing the Differences in Sub-County Schools Mathematics Teachers' Attitudes Mean Scores towards Mixed and Gender Streamed (Girls' and Boys' Only) Classes.

\begin{tabular}{llllll}
\hline & Sum of squares & df & Mean square & F & P-value \\
\hline $\begin{array}{l}\text { Between } \\
\text { groups }\end{array}$ & 1.225 & 2 & 0.613 & 2.47 & 0.090 \\
$\begin{array}{l}\text { Within groups } \\
\text { Total }\end{array}$ & 23.564 & 95 & 0.248 & & \\
\hline
\end{tabular}

$\mathrm{df}=2,95 ;$ F-critical $=3.07 ; \mathrm{P}<0.05$

The ANOVA results indicate that there is no statistically significant difference in mathematics teachers' attitudes towards mixed and gender streamed classes within sub-county co-educational secondary schools. Based on these findings, the null hypothesis that states that there is no statistically significant difference in mathematics teachers' attitudes towards gender streamed and mixed sex classes within district co-educational secondary schools is therefore accepted.

Table 4. Mean Scores and Standard Deviation (SD) of County Schools' Mathematics Teachers' Attitudes towards Gender Streamed (Girls' and Boys ' only) and Mixed Sex Classes.

\begin{tabular}{llll}
\hline Class Type & N & Mean Score & SD \\
\hline Boys' Only & 40 & 4.38 & 0.35 \\
Girls' Only & 25 & 4.04 & 0.68 \\
Mixed Sex & 40 & 4.30 & 0.06 \\
\hline
\end{tabular}

From the overall mean scores, the results indicate that the mean scores were higher for teachers teaching boys' only classes with a mean score of 4.38 followed by those teaching mixed sex classes with a mean score of 4.30 and finally those teaching girls' only classes with a mean score of 4.04 out of a maximum of 5 . This findings indicate that the teachers' attitudes towards girls only mathematics classes were lower than the others. The results are similar to those found in district schools. In order to determine whether the mean scores were statistically significant ANOVA was performed and the results summarized in Table 5 .

Table 5. ANOVA Results showing the Differences in County Schools' Mathematics Teachers' Attitudes towards Mixed and Gender Streamed (Girls' and Boys' Only) Classes.

\begin{tabular}{llllll}
\hline & $\begin{array}{l}\text { Sum of } \\
\text { squares }\end{array}$ & df & Mean square & F & $\begin{array}{l}\text { Sig } \\
\text { (P-value) }\end{array}$ \\
\hline $\begin{array}{l}\text { Between } \\
\text { groups }\end{array}$ & 1.821 & 2 & 0.911 & 4.163 & 0.018 \\
$\begin{array}{l}\text { Within groups } \\
\text { Total }\end{array}$ & 22.311 & 102 & 0.219 & & \\
\hline
\end{tabular}

$\mathrm{df}=2,102 ;$ F-critical $=3.07 ; \mathrm{P}<0.05$

The ANOVA results in Table 5 indicate that there is a statistically significant difference in mathematics teachers' attitudes towards mixed and gender streamed classes within the county co-educational secondary schools. Therefore, the null hypothesis that states that there is no statistically significant difference in mathematics teachers' attitudes towards gender streamed and mixed sex classes within county 
co-educational secondary schools is therefore rejected. The findings indicate that there are differences in mathematics teachers' attitudes towards girls' only, boys' only and mixed sex classes within the county co-educational secondary schools. In order to determine the direction of the difference, a post hoc multiple comparison test using the scheffe was performed and the results obtained reported in Table 6 .

Table 6. Post Hoc Comparisons of the County Schools'Mathematics Teachers Attitudes Mean Scores.

\begin{tabular}{llll}
\hline $\begin{array}{l}\text { I Gender } \\
\text { composition of } \\
\text { maths class }\end{array}$ & $\begin{array}{l}\text { J Gender } \\
\text { composition of } \\
\text { maths class }\end{array}$ & $\begin{array}{l}\text { Mean } \\
\text { Differences (I-J) }\end{array}$ & P-value \\
\hline Boys & Girls & $0.3374^{*}$ & 0.021 \\
& Mixed & -0.2609 & 0.766 \\
Girls & Boys & $-0.3374^{*}$ & 0.021 \\
& Mixed & -0.2609 & 0.096 \\
Mixed & Boys & -0.0765 & 0.766 \\
& Girls & -0.2609 & 0.096 \\
\hline
\end{tabular}

* Means significant at P-Value $<0.05$ level

Critical values $\mathrm{F}(\mathrm{df} 2,102, \alpha=0.05)=3.07$

Table 7. Post Hoc Results showing the Pairs of Mathematics Classes that Differed Significantly in Teachers' Attitudes.

\begin{tabular}{|c|c|c|c|c|}
\hline Item & $\begin{array}{l}\text { I Gender } \\
\text { Class }\end{array}$ & $\begin{array}{l}\text { J Class } \\
\text { Gender }\end{array}$ & $\begin{array}{l}\text { Mean } \\
\text { differences (I-J) }\end{array}$ & p-value \\
\hline \multirow{6}{*}{$\begin{array}{l}\text { 1. Teaching } \\
\text { mathematics in my } \\
\text { class is very interesting } \\
\text { and I enjoy it }\end{array}$} & \multirow[t]{2}{*}{ Boys } & Girls & $0.4650 *$ & 0.034 \\
\hline & & Mixed & -0.3150 & 0.626 \\
\hline & \multirow[t]{2}{*}{ Girls } & Boys & $-0.4650 *$ & 0.034 \\
\hline & & Mixed & -0.3150 & 0.207 \\
\hline & \multirow[t]{2}{*}{ Mixed } & Boys & -0.1500 & 0.626 \\
\hline & & Girls & 0.3150 & 0.207 \\
\hline \multirow{6}{*}{$\begin{array}{l}\text { 2. I do not always like } \\
\text { teaching mathematics } \\
\text { in this class and it } \\
\text { scores me to have to } \\
\text { teach it }\end{array}$} & \multirow[t]{2}{*}{ Boys } & Girls & $0.4950 *$ & 0.002 \\
\hline & & Mixed & 0.0250 & 0.979 \\
\hline & \multirow[t]{2}{*}{ Girls } & Boys & $-0.4950 *$ & 0.002 \\
\hline & & Mixed & $-0.4700 *$ & 0.004 \\
\hline & \multirow[t]{2}{*}{ Mixed } & Boys & -0.0250 & 0.979 \\
\hline & & Girls & $0.4700^{*}$ & 0.004 \\
\hline \multirow{6}{*}{$\begin{array}{l}\text { 3. Teaching } \\
\text { mathematics in this } \\
\text { class is fascinating and } \\
\text { fun }\end{array}$} & \multirow[t]{2}{*}{ Boys } & Girls & $0.5650^{*}$ & 0.036 \\
\hline & & Mixed & 0.0000 & 1.000 \\
\hline & \multirow[t]{2}{*}{ Girls } & Boys & -0.5650 & 0.036 \\
\hline & & Mixed & -0.5650 & 0.036 \\
\hline & \multirow[t]{2}{*}{ Mixed } & Boys & 0.0000 & 1.000 \\
\hline & & Girls & $0.5650 *$ & 0.036 \\
\hline \multirow{6}{*}{$\begin{array}{l}\text { 4. Teaching this class } \\
\text { mathematics makes me } \\
\text { feel secure and } \\
\text { stimulated }\end{array}$} & \multirow[t]{2}{*}{ Boys } & Girls & $0.5800^{*}$ & 0.021 \\
\hline & & Mixed & -0.1750 & 0.623 \\
\hline & \multirow[t]{2}{*}{ Girls } & Boys & $-0.5800^{*}$ & 0.021 \\
\hline & & Mixed & $-0.7550 *$ & 0.002 \\
\hline & \multirow[t]{2}{*}{ Mixed } & Boys & 0.1750 & 0.623 \\
\hline & & Girls & $0.7550 *$ & 0.002 \\
\hline \multirow{6}{*}{$\begin{array}{l}\text { 5. Teaching } \\
\text { mathematics in this } \\
\text { class is something } \\
\text { which I enjoy a great } \\
\text { deal }\end{array}$} & \multirow[t]{2}{*}{ Boys } & Girls & $0.4800 *$ & 0.049 \\
\hline & & Mixed & 0.3250 & 0.162 \\
\hline & \multirow[t]{2}{*}{ Girls } & Boys & $-0.4800 *$ & 0.049 \\
\hline & & Mixed & -0.1550 & 0.724 \\
\hline & \multirow[t]{2}{*}{ Mixed } & Boys & -0.3250 & 0.162 \\
\hline & & Girls & 0.1550 & 0.724 \\
\hline \multirow{6}{*}{$\begin{array}{l}6 . \text { I am able to teach } \\
\text { my class mathematics } \\
\text { without too much } \\
\text { difficulty }\end{array}$} & \multirow[t]{2}{*}{ Boys } & Girls & $0.5650 *$ & 0.902 \\
\hline & & Mixed & 0.0750 & 0.881 \\
\hline & \multirow[t]{2}{*}{ Girls } & Boys & $-0.5650 *$ & 0.902 \\
\hline & & Mixed & -0.4900 & 0.667 \\
\hline & \multirow[t]{2}{*}{ Mixed } & Boys & -0.0750 & 0.881 \\
\hline & & Girls & 0.4900 & 0.667 \\
\hline
\end{tabular}

Critical values $\mathrm{F}(\mathrm{df}=2,102, \alpha=0.05)=3.07$
The post Hoc results in Table 6 indicate that there are statistically significant differences between the mean scores of mathematics teachers attitudes teaching students in boys' and girls' only classes favoring the boys. However, the attitudes mean scores obtained by teachers teaching learners in girls' only and mixed sex classes were not significantly different. This difference could be attributed to the poor performance of girls in mathematics as compared to the boys. It could also mean that these teachers are anxious during instruction due to lack of appropriate skills and knowledge of gender related classroom techniques and practices. Further, Post Hoc tests were performed for each individual attitude item. Table 7 summarizes the post hoc results of the attitude items with statistically significant differences.

The results in Table 7 indicate that the attitudes of mathematics teachers teaching boys' only and girls' only classes significantly differed at $\alpha=0.05$ in favour of boys in all the six items. The results also indicate that the same teachers' attitudes differed significantly between teachers teaching girls' only and mixed sex classes in items 2, 3, 4 in favour of mixed sex classes at $\alpha=0.05$. This is an indication that mathematics teachers prefer teaching boys' only and mixed sex classes as opposed to girls' only classes.

\section{Discussion}

This study compared mathematics teachers' attitudes between those who teach gender streamed (boys' and girls' only) and mixed sex classes in the sampled schools. The findings of the study have shown that mathematics teachers' attitudes towards gender streamed (girls' and boys' only) classes and mixed sex classes are positive. The findings indicate that in sub-county schools, mathematics teachers' attitudes were higher in boys' only with a mean of 4.23 , followed by mixed sex with a mean of 4.13 and lastly girls' only with a mean of 3.95 out of the highest possible score of 5 points. In the case of county schools, findings show that the teachers attitudes were higher in boys' only classes with a mean score of 4.38 followed by mixed sex with a score of 4.30 and finally girls' only with a mean score of 4.04 .

From the results, it is clear that the attitude mean scores were generally higher in county schools for each corresponding class type than sub-county schools. This could be attributed to the fact that students admitted in county schools perform better in mathematics than their counterparts in sub-county schools since they were admitted to secondary school with higher Kenya Certificate of Primary Education (KCPE) scores in primary school than those in sub-county schools. This could imply that the academic ability level of the learners may influence the teachers' attitude towards his or her classes. It is also clear from the findings that these teacher attitudes were lower in girls' only classes in both sub-county and county schools.

There were no statistically significant differences in mathematics teachers' attitudes towards gender streamed (boys' and girls' only) and mixed sex classes in sub-county schools. However, statistically significant differences existed 
in teachers' attitudes in the county schools. The findings indicate that there were statistically significant differences in the mathematics teachers' attitudes towards boys' and girls' only classes in favour of boys' only classes. It is important to note that a majority of county schools were boarding schools and most parents prefer taking their daughters who obtain good grades in KCPE to single-sex girls' only schools. This implies that there existed gender differences in general performance in favour of boys at admission to secondary school. The gender difference in ability levels favoring boys in county schools could explain the difference in teacher attitudes.

The findings of this study seem to agree with those of Mukwa and Too (2005) who argue that teachers' treatment of boys and girls in class conform to societal stereotypes. These stereotypes seem to allude to the fact that boys should be superior in mathematics. This may explain why mathematics teachers have more positive attitudes towards boys' only classes as opposed to girls' only classes. The findings also agree with Gina and Moshe (2001) who asserts that teachers view boys as their best mathematics students, hence concentrate more on them than the girls. This study has demonstrated that despite the creation of separate classes for the sexes in co-educational schools, teachers still feel that boys are better learners of mathematics than girls.

However, the findings of this study contradicts those of Rennie and Parker (1997) who found that the single - sex classroom environment resulted in improved teacher attitudes towards boys and girls as learners of mathematics. Rennie and Parker argued that single sex learning environments provided the teachers with opportunities to address apparent gender related short comings arising from boys' and girls' previous educational experiences.

\section{Conclusion}

Based on the findings of the study, it is concluded that the mathematics teachers' attitudes towards gender streamed (boys' and girls' only classes) and mixed sex classes in both district and county categories of co-educational secondary schools were positive. Their mean scores were higher in boys' only classes followed by mixed sex and lastly girls' only classes in the two school categories. Further, these teacher attitudes did not differ significantly in sub-county schools but differed significantly in county schools between boys' only and girls' only classes in favour of boys' only classes.

\section{Implication}

The study findings indicate that mathematics teachers attitudes towards gender streamed and mixed sex classes in sub-county and county schools are positive. However, their attitude mean scores are lower in girls' only classes. This implies that mathematics teachers do not like teaching girls' only mathematics classes' as much as mixed sex and boys' only classes. This finding seems to suggest that there is need to provide more in-service courses to these teachers so that their attitudes towards these classes may improve. It could also imply that teachers are not well prepared to handle girls' only mathematics classes.

\section{Recommendation}

In view of the conclusion the following recommendation was made; the Ministry of Education through the Quality Assurance and Standards Officers should establish why mathematics teachers have lower attitudes of girls' only classes. They should thereafter organize intensive in-service training for the mathematics teachers.

\section{Recommendation for Further Research}

A qualitative study should be undertaken to establish the reasons for lower mathematics teachers' attitudes of girls' only classes.

\section{References}

[1] Ahmad, A. \& Sahak, R. (2009). Teacher - Student Attachment and Teachers' Attitudes Towards Work. Available online http://www.usm.my/education/publication/JPP24 - Affizal - 55 -72 . Pdf.

[2] Ahuja, O. P. (2006). World-Class High Quality Mathematics Education for all K - 12 American Students, Department of Mathematical Science, Kent State University. The Montana Mathematics Enthusiast, ISSN 1551 - 3440, Vol 3 No. 2, Pp.223 - 248 (C) The Montana Council of Teachers of Mathematics.

[3] Carr, M. (2000). The Role of Context and Development from Lifespan Perspective. In W. Schneider and F. E. Weinert (eds.). Interactions among aptitudes, strategies and knowledge in cognitive performance. New York: Spring Verlag, 222 - 231.

[4] Chouinard, R. (2008). Coeducational of Single-Sex School: Does it make a Difference on high School Girls'Academic Motivation? Educational Studies, 34(2), 129-144.

[5] Cohen, L., Manion, L., \& Morrison, K. (2011). Research Methods in Education $\left(5^{\text {th }} \mathrm{ed}\right)$. London \& New York: Routledge Falmer.

[6] Fryer, R., \& Levitt, S. (2010). "An Empirical Analysis of the Gender Gap in Mathematics" American Economic Journal: Applied Economics, Vol.2 (2), pp.210-240.

[7] Gall, P. G., Gall, M. D. \& Borg, W. R. (2007). Educational Research. An Introduction ( $8^{\text {th }}$ ed), Pearson Education. Inc.

[8] Gina, E. \& Moshe, T. (2001). Teachers' Perceptions of their Students Gender Roles. The Journal of Educational Research. Available online; http://www.highbeam.com/doc/IGI 95631113.html.

[9] Hiken, (1982). Psychological Testing and Assessment $4^{\text {th }}$ ed. London, Ally and Becon Inc.

[10] Hodgen, J., \& Marks, R (2013). The Employment Equation: Why our Young People Need More Maths for Todays Jobs. London. 
[11] Husen, T \& Postlethwaite, T. N. (1991). Cognitive Styles. In The international encyclopedia of Education (Vol. 2, pp868-871) New York, Pergamon press.

[12] Kenya National Examinations Council (KNEC). The year 2003 - 2013 Kenya Certificate of Secondary Examinations (KCSE) Candidates Performance Reports. Nairobi: KNEC.

[13] Kreiter, R. \& Kinicki, A. (2007). Organizational Behavior, Arizona: McGraw - Hill Ryerson.

[14] McCoy, S., Smyth \& Burke (2012). "The Primary Classroom: Insights from the Growing up in Ireland Survey"Economic and Social Institute Working Paper.

[15] Mukwa, C. W. \& Too, J. K. (2005).Gender and Classroom Challenges of Teaching Mathematics in Secondary Schools in Kenya. Journal of Education and Human Resources, Vol. 3 No. 2: pp 116 - 127, Egerton University

[16] Norris, E. (2012). Solving the Maths Problem: International Perspectives on Mathematics Education. London.
[17] Offsted (2011).Good Practice in Primary Mathematics. Manchester: Offsted.

[18] Pahle, E., Hyde, J. S., \& Allison, C. M. (2014).The Effects of Single- Sex Compared with Co-educational Schooling on Students Performance and Attitudes: A Meta-Analysis. American Psychological Association.doi:10.1037/a0035740.

[19] Rennie, L. J., \& Parker, L. H. (1997).Students' and Teachers' Perceptions of Single-Sex and Mixed-Sex Mathematics Classes. Mathematics Education Research Journal, 9, (3), 257-273.

[20] Rose, M. (2005). Lives on the Boundary, New York: Penguin Books.

[21] Teo, (2008). Pre-Service Teachers' Attitudes Towards Computer Use: A Singapore Survey. Australian Journal of Educational Technology 24 (4), 413 - 424(online) Available: http://www.ascilite.org.au/ajet/aget 24/teo.html. 